\title{
E-Government Based Public Services in Medan Barat Subdistrict
}

\author{
Muhammad Iqbal $^{1}$, Julia Ivanna ${ }^{2}$, Prayetno $^{3}$, Yessi Yunelva Sinaga ${ }^{4}$ \\ \{iqba181@unimed.ac.id ${ }^{1}$,juliaivanna@unimed.ac.id ${ }^{2}$, eno.pray@gmail.com ${ }^{3}$,yessinaga98@gmail.com ${ }^{4}$ \} \\ Department of Anthropology Education,Universitas Negeri Medan, Indonesia ${ }^{1}$ \\ Department of Civic and Pancasila Education, Universitas Negeri Medan, Indonesia ${ }^{2,3,4}$
}

\begin{abstract}
This article discusses government efforts in the implementation of bureaucracy reform as stipulated in the law No. 25 of 2009 about public services related to the service to its residents with quality service standards, fast, easy, affordable and be measured. It is in accordance with Presidential Instruction No. 3 of 2003 about national policy on $e$ Government development.In its development, e-Government is still far from expectations, government institutions both in the center and the region do not yet consider the important e-Government. E-Government is considered a project and a momentarily trend. Kecamatan Medan barat is one of the sub-districts in Medan that has been conducting bureaucracy reform by providing public services based on electronic (ekecamatan) in managing Administration andIncrease Community participation. The results showed the success of public services electronic-based public services in Kecamatan Medan Barat had a prerequisite, namely (1) the support from the District Leadership (Camat), (2) availability of Financial Resources and Human Resources (3) Transparency In the public service process with application system. In addition, ekecamatan based services facilitate the residents to obtain information and manage various purposes in the form of administrative services products.
\end{abstract}

Keywords: bureaucratic reform, public service, e-kecamatan

\section{Introduction}

Along with the development of information and communication technology, the state in this case the government is required to be part of the global community. Technology has become a fundamental demand of public services carried out by the government in order to achieve effective and efficient public services. There has been a change in the utilization of Information, Communication and Technology (ICT) where human activities in various sectors have also changed, as well as in the public service sector by the government.

Government efforts in implementing bureaucratic reform as regulated in Law no. 25 of 2009 concerning Public Services which is providing services to its citizens with quality standards of service, fast, easy, affordable and measurable continues to be done [1].The government's efforts were supported by the issuance of Presidential Instruction Number 3 of 2003 concerning the National Policy for the Development of E-Government in the administration of electronic-based government or often referred to as Electronic Government (e-government) [2].

The use of e-Government in order to realize the principles of open government has been regulated in Law No. 14 of 2008 concerning Openness of Public Information where every 
citizen has the right to obtain public information [3]. The use of e-Government at the local government level is still based on the initiative and commitment of regional heads[4][5]. These innovations are related to the use of information and communication technology in supporting services to the community.

In its development, e-Government is still far from expectations. Government institutions both at central and regional levels do not yet consider e-government importance. EGovernment is considered as a project and momentary trend in government circles. found that some local government websites are not well managed and maintained [6].That financial information uploaded on government sites is still difficult to understand, and the public still has limited access. The limited regulation as a legal umbrella and the limited competent experts in the field of informatics engineering are obstacles to the success of e-Government. Not yet integrated data between government agencies is also an obstacle because each agency has one data program with a different format. Inadequate budgeting, lack of standardization of infrastructure and the lack of information security in implementing e-Government are also cited as the causes of e-Government's lack of success so far [7].

Kecamatan Medan Barat, one of the sub-districts in the city of Medan, which has now carried out bureaucratic reform by signing a service announcement to carry out public services in accordance with the Service Standards that have been set in accordance with applicable laws and regulations. Ironically, the website of Medan Barat District shows that the website is left neglected, lacks information and data, even the website has not been updated for a long time. So far, it has been very difficult to get data from the official government website.

\section{Method}

This study uses qualitative research methods with the type of descriptive research. The use of descriptive types is intended as a problem-solving procedure that is investigated by describing or describing the condition of the subject or object under study (a person, institution, society, etc.) at the present time based on the facts that appear or as they are [8]. The focus of this research is the implementation of the E-Government program in the Medan Barat District in the City of Medan. This research tries to describe the phenomena / events that exist in the application of E-Government in the Kecamatan Medan Barat in the City of Medan as a form of service to the public using information technology in its implementation.

\section{Result and discussion}

The Office of Communication and Information as the person in charge of E-Government Development in Medan City is required to be able to meet the needs and provide the best service to realize the vision and mission of e-Government. If you follow the Presidential Instruction E-Government should have been carried out since 15 years ago. On the island of Java e-Government has been implemented in the last 10 years, whereas in Medan itself it has only been running for 3 years. The vision and mission are elaborated in the form of Mayor Regulation (Perwal), namely the existence of Perwal No. 28 of 2018, then proceed with the issuance of Mayor Decree related to ICT services where this regulation is in the form of smart city council for the period of 2017-2020[9]. Not all OPDs belong to the smart city team. The 
smart city team only consists of the OPD who need a special system. With the Perwal Medan Smart City, Medan City signed an MoU with Tangerang City in September 2018. Medan City succeeded in getting a ranking of 43 out of 140 Smart City cities in Indonesia.

Medan city entered into an MoU with Tangerang in the form of using a sharing application, the reason is that the sharing application can save a budget. Estimated budget that will be issued by Medan City Government makes a program to create an application cost hundreds of millions. But it will be greatly helped in terms of costs if entering into cooperation or an MoU with other cities or districts that have already developed the EGovernment or Smart City ecosystem. With this MoU, Medan City can adopt and modify it without the need to design. Modification of the application is needed because it must be adapted to the needs of the City of Medan. Medan's e-Government needs are certainly not the same as the needs of other cities. So that if you are going to adopt an e-Government application it can't necessarily be used directly from the place of origin but it certainly has to be adjusted so that it doesn't cause friction due to non-compliance needs. This is influenced by culture, geographical location and others.

For the OPD level, each determines its own menu needs, features and content on the website. Only basic web from Diskominfo. Uniformity of menus for basic public services such as requests for making E-KTPs, heirs in each district is very important. However, not all districts run public services based on E-Government (e-kecamatan). In matters relating to eGovernment development budgets sourced from the APBD where the proposed budget is submitted annually. Diskominfo only issues budgets when making applications and installing wifi, whereas once the web and wifi are available it will be submitted to each OPD.For the budget proposal, the proposed $100 \%$, the percentage of proposals which realized $90 \%$.

In 2019 the budget to deal with ICT and the success of E-Government is 30 billion. Actually, if you want to build a large ICT should also have a large budget. For example the city of Bandung has a command center and builds with funds of nearly 30 billion. The Diskominfo budget is one tenth of the Bandung city government budget for one program. That means the same as the one-year Diskominfo budget with many activities. These funds must be accommodated for all network interests in the Medan City Government. Although actually still very minimal.

The procedure for submitting the budget is carried out in a joint meeting with the head of the budget, section heads, division heads, secretaries, heads and department heads. The proposal is made by budgeting by first detailing the use of funds. With a limited budget, not all applications proposed by OPD are approved. Medan City Diskominfo made a policy to make one application each year because it was not possible to build applications with inadequate budgets. With these budget considerations, the Diskominfo conducted a selection on the basis of the development and evaluation of the subdistrict and kelurahan conducted by the Medan city government every year. Diskominfo will prioritize sub-districts or villages that excel such as Lauci, Silalas, Karang Berombak. For 21 districts in the city of Medan, they have used a website that is integrated with several applications and is connected to the website of the Medan City Government. Whereas at the moment there are 12 villages that use the website.

The availability of financial resources is very much needed for the successful development of E-Kecamatan. In terms of budget, each sub-district proposes a different nominal as needed in applying the E-Subdistrict application to the Medan City Government. Human resources are the main and most important asset in carrying out the management and operations of the organization. Qualification of human resources both educational background and experience in their fields will determine the success of the organization's tasks and functions. When viewed from qualifications or educational background, the Medan Office of 
Communication and Information does not yet have a good staffing structure. The weakness is particularly evident in the educational background where only 8 civil servants or 0.19 percent have an educational background that matches the field of work handled by the Diskominfo.

Furthermore, for the availability of human resources in the kecamatan Medan Barat, where the availability of experts for E-Subdistrict services consists of two people with a Bachelor's education background in economics.Availability of adequate information technology infrastructure is $50 \%$ of the keys to the successful implementation of EGovernment[10] In terms of infrastructure, the Medan City Government provides internet network (wifi) and continues to work closely with telecommunications service providers. Telkom, Indosat and other providers such as PLN, TNC, INET, MEDIA NUSA, city hall from PRESS MEDIA (CHANNEL TV ) so that E-Government can be accessed by the public.For the smooth implementation of E-Kecamatan in Medan Barat, there are already computers and other supporting infrastructure available to support the implementation of E-kecamatan. The official appearance of the Kecamatan Medan Barat website can be seen in www.medanbarat.pemkomedan.go.id

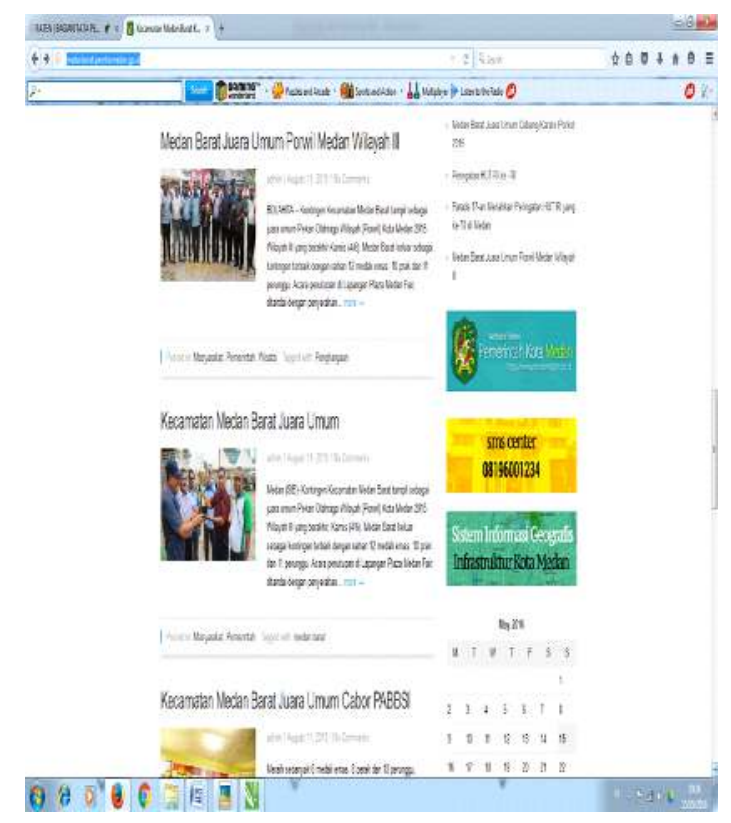

Fig. 1. Website of the Medan Barat subdistrict

The types of information displayed on the West Medan District Government website are several categories including: Religion, Health, Community, Sports, Market, Government, Education, Art, Uncategorized, Tourism. These categories provide various information and news about the activities, work programs and policies of the West Medan District Government as an extension of the Medan City government. In terms of the use of social media the West Medan District Government is very active both on Twitter, Facebook and Instagram, because almost all the people have social media so this is a strategy of the West Medan District Government to provide information and greet their citizens. For social media use only Twitter 
is linked to the website. The aim is to report routine sub-district activities, such as mutual cooperation which is held every Tuesday and Thursday. Documentation of activities uploaded to social media in order to be able to notify and invite the public to participate. According to the explanation from the sub-district, social media is much more desirable than the website.

The platform uses Indonesian, where direct communication cannot be done on the website between the West Medan District Government and the community, because the information processing is still offline.E-subdistrict is an online application service districts. E-Kecamatan is a subdistrict-level administrative management website designed and developed by the Medan city government to provide convenience to the people of Medan Barat District. Previously, the E-Kecamatan application system that would be built was first discussed with Diskominfo so that it could be made as easy and as simple as possible so that residents could use it.

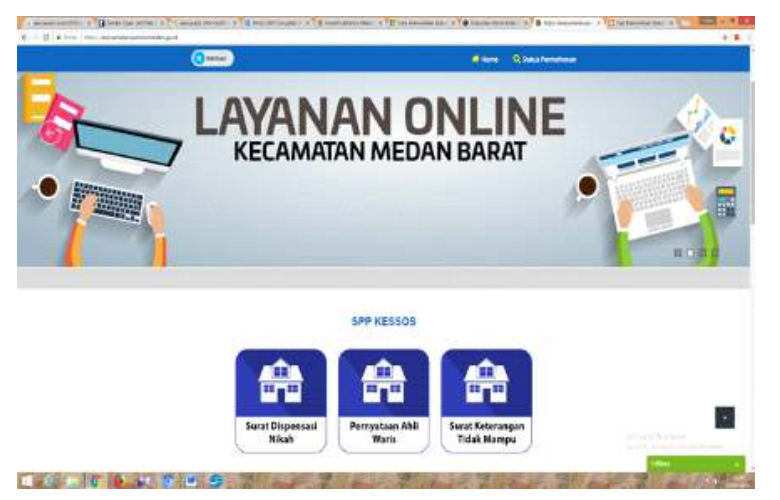

Fig. 2. Web Display of E-Kecamatan Medan Barat

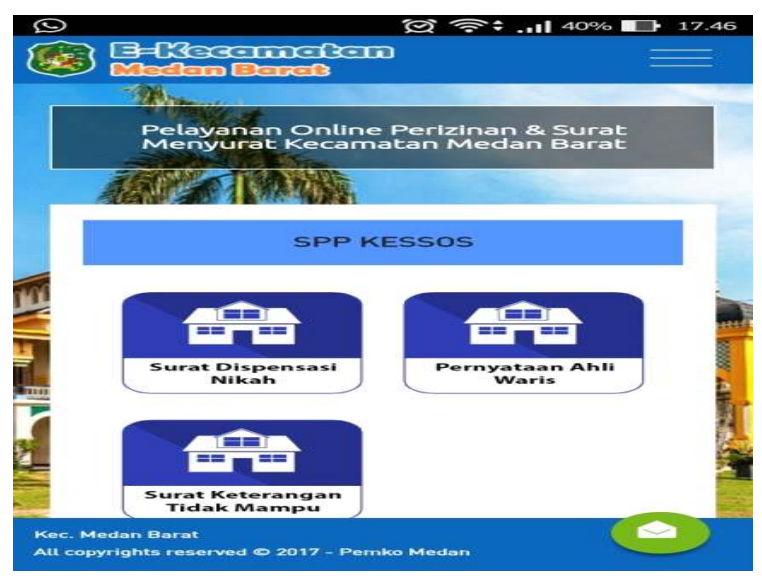

Fig. 3. Web for Android version 
West Medan Sub-District residents can download the E-Sub-district application where in the application there are 5 types of services available including New Indonesian Citizenship Card Requests, Indonesian Citizenship Card Requests, Indonesian Citizenship Card Requests ( E-KTP) New Indonesian Citizen, Request for Heir's Statement, Request for Moving Certificate of Arrival. In the settlement of correspondence, the sub-district cannot process and finish the product directly, for example in the handling of the Family Card (KK) in the subdistrict, it cannot be finished immediately, but there is still a further process whereby the files will be submitted to the office, the task of the sub-district is only to process in attaching data or as intermediaries, after that will be sent to Disdukcapil.

Similarly in the management letter moved away, first obtaining a letter from the head of the environment and then scanned along with the ID card and family card. Subsequently uploaded to the E-district application. Kecamatan Medan Barat built an android application system to support the District administration service products. Through the E-Kecamatan application, the people of the West Medan sub-district who want to get administrative services can directly use an android smartphone or open the E-Kecamatan website at the link http://medanbarat.pemkomedan.go.id/

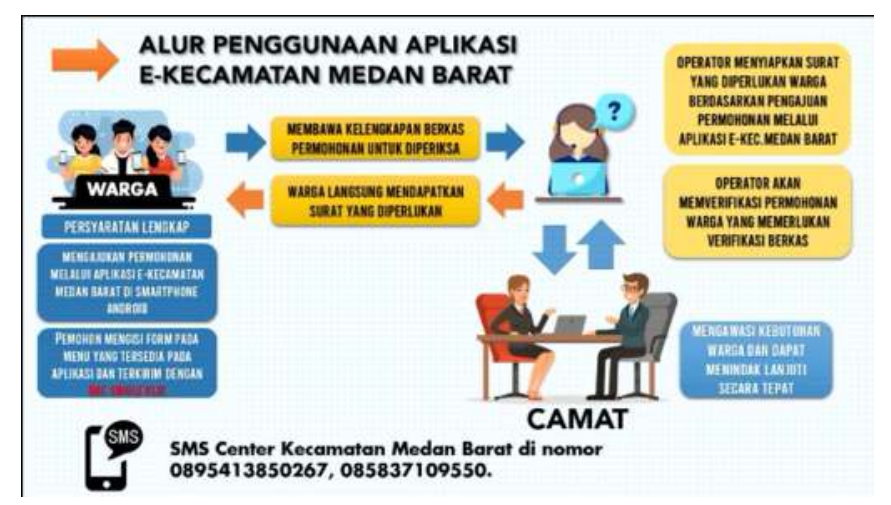

Fig. 4. E-Kecamatan procedures

Support and capacity elements are aspects that are viewed from the government side in providing public services (supply side). Both of these elements can be useful if they can provide benefits for the interests of the community (demand side).For this reason, careful government is required in choosing the priority types of e-Government applications. What types of applications should take precedence in order to truly provide benefits (value) that are significantly felt by the community[11].

According to the results of interviews with several people who use the website and application of the West Medan District government, the community felt helped because in administrative matters there was no need to commute to the sub-district office. Only need to complete the file and send the requirements into the application according to the required administrative application. It's just that in the process of completing several types of services takes quite a long time. This is because the final product in the administration process needed by the community cannot be completed in the sub-district. The product is completed at the relevant office as in the management of e-KTP the final product is completed at the Population and Civil Registry Office. 
The benefits of E-Kecamatan applications are also only felt by some people who understand how to use technology. The society consists of millennials and workers who are already familiar with using technology. Whereas for the elderly lay people it's easier to take care of administration by hand or by coming directly to the district office.

\section{Conclusion}

From the results of the study it can be concluded that the implementation of eGovernment based public services has optimally. This can be seen from the high commitment of leaders.Public services through e-kecamatan is the answer or response from the government of Kecamatan Medan barat on the demand to improve the quality of public services, especially in administrative services will be more effective and efficient.The benefit of using the ekecamatan application is that citizens can access various information and take care of the needs related to administrative service products, such as family card applications (Kartu keluarga), E-KTP, application for moving certificates) easily and quickly.

\section{References}

[1] P. I. Indonesia, Undang-Undang Republik Indonesia No. 25 Tahun 2009 Tentang Pelayanan Publik. 2015.

[2] P. R. Indonesia, "Instruksi Presiden Republik Indonesia Nomor 3 Tahun 2003 tentang Kebijakan dan Strategi Nasional Pengembangan E-Government.” Deputi Sekretaris Kabinet Bidang Hukum dan Perundangundangan, 2006.

[3] R. I. Indonesia, "Undang-Undang Republik Indonesia No. 14 Tahun 2008 Tentang Keterbukaan Informasi Publik," 2015.

[4] B. Rahardjo, "Membangun e-government," in Makalah dipresentasikan pada Seminar Nasional Jaringan Komputer II diselenggarakan oleh Technic Study Club, STMIK Dipanegara Makassar, 2001, vol. 19.

[5] E. A. Sosiawan, "Evaluasi implementasi e-government pada situs web pemerintah daerah di Indonesia: Prespektif content dan manajemen," in Seminar Nasional Informatika (SEMNASIF), 2015, vol. 1, no. 5 .

[6] Y. C. Chen and J. Gant, "Transforming local e-government services: The use of application service providers," Gov. Inf. Q., vol. 18, no. 4, pp. 343-355, 2001.

[7] N. Hidayati, "E-GOVERNMENT DALAM PELAYANAN PUBLIK (Studi Kasus tentang Faktor-faktor Penghambat Inovasi Layanan E-Samsat Jatim di Kabupaten Gresik)," Mhs. Progr. Stud. Ilmu Adm. Negara, FISIP, Univ. Airlangga, Kebijak. dan Manaj. Publik, vol. 4, 2016.

[8] J. W. Creswell and J. D. Creswell, Research design: Qualitative, quantitative, and mixed methods approaches. Sage publications, 2017.

[9] A. Ricky, "SK SMART CITY 2018," 2018.

[10] I. R. Eko, "E-Goverment in action," Andi, Yogyakarta, 2005.

[11] R. Heeks, Reinventing government in the information age: International practice in IT-enabled public sector reform, vol. 1. Psychology Press, 2001. 
